\title{
Turning cross-cultural management conflict into collaboration: Indian and Romanian experiences in Global Project Teams
}

\author{
Corina AGARICI \\ Doctoral School of Entrepreneurship, Business Engineering and Management, Bucharest, \\ Romania \\ corina_agarici@hotmail.com \\ Cezar SCARLAT \\ Doctoral School of Entrepreneurship, Business Engineering and Management, Bucharest, \\ Romania \\ cezarscarlat@yahoo.com \\ Danuţ IORGA \\ Doctoral School of Entrepreneurship, Business Engineering and Management, Bucharest, \\ Romania \\ iorgadanut@gmail.com
}

\begin{abstract}
Global project virtual teams are increasingly common as organizations strive to maintain a global presence, find top and diverse talent, and cope with economic constraints. They include members from multiple nations and cultures who must work together while being separated by time and space. An internal research, which has been conducted in an international company active in the industrial sector of financial services, provides few insights into how integrating the Western values of individualism and low power distance with the Eastern values of collectivism and high power distance may influence cross-cultural conflict management. The purpose of this paper is to directly examine the impact of organization-level collectivism and individualism as well as high and low power distance-in case of global project teams that include Romanian and Indian experts - in order to determine the interactive effects of these factors on crosscultural conflict management. The authors sustain the idea that understanding intercultural dynamics can facilitate collaboration and reduce conflicts in intercultural encounters at the individual, organization, and probably societal levels. Methodological approach is to use both secondary literature survey and primary research methods as interviews and short case-examples from authors' direct consulting experience while working with global project teams. This pilot study - as part of a larger research project - contributes to fill one gap in the understanding of culturally heterogeneous project teams and is the starting-point for additional investigation in this area.
\end{abstract}

Keywords: Cross-cultural management conflicts, Intercultural collaboration, Individualism/collectivism, Low/high power distance, Global project teams, Financial services industry, Romanian versus Indian cultures.

\section{Introduction}

When employees enter another nation, they tend to suffer cultural shock, which is the insecurity and confusion caused by encountering a different culture. They may not know how to act, may fear losing face and self- confidence, or may become emotionally upset. Some individuals isolate themselves, while a few even decide to return home on the next airplane. It is virtually universal. It happens even on a move from one advance nation to another. 
This study considers the cross-cultural relationships in the case of global project teams acting in the financial services industry. In particular, the main objective of the study is to analyse the inter-cultural relationships that occur in global project teams with Indian and Romanian people, from the Romanians' standpoint, with focus on the turning cross-cultural management conflict into collaboration. For this purpose, the study considered an organizational cultural framework using the Hofstede's six dimensions model (Hofstede, 1991, 2003). Consequently, the paper is structured PICBE | 1025 along these lines: short literature survey; investigation methodology; Romanian versus Indian cultural dimensions analysed - emphasizing power distance and individualism; causes of intercultural conflicts and case-examples in global project teams: Romanian versus Indian cultures; results and discussion; lessons learnt; conclusions and further research avenues.

\section{Literature survey}

We face conflicts often as we encounter contradictory goals (Northouse, 2011; Proksch, 2016). Choosing between communism, dictatorship, and democracy, conflict is unavoidable; fortunately, we can learn to transcend conflict as we avoid false dichotomies. Several emotions emerge from conflict, for example: fear or anxiety result from a conflict between the need for safety and an actual or imagined threat: anger results from a conflict between your goals, including your sense of justice and actual events; guilt, shame and contempt result from a conflict between a desirable standard of behaviour and actual behaviour; envy and jealousy result from a conflict between what you want and what you have. That can be explained as a result of knowledge dynamics (Bratianu \& Bejinaru, 2019, 2020). When you blame another for causing conflict, you may come to hate them. Ambivalence describes a conflict within yourself and inability to choose a clear goal or direction. In general, there are four types of conflicts as presented by Gallow (2015) and their management is schematically presented in Figure 1, as adapted by Landers (2017) from Eunson (2009) - known as Thomas-Kilmann Conflict Mode Instrument (TKI). Failure in addressing the conflicts impacts the organization's performance.

Nowadays, due to globalization, many companies are operating in more than one country. This crossing of geographical boundaries by the companies gives the birth of multicultural organization where employees from more than one country are working together. However, cultural differences can interfere with the successful completion of organizational goals in today's multicultural global business community (Kotter and Heskett, 1992; Black, 2003; Ganescu, 2011).

To avoid cultural misunderstandings caused by cultural differences (Triandis, 1982; Raymonde, 1998) that might develop into conflicts (Zarzu and Scarlat, 2014, 2015), managers should be culturally sensitive and promote creativity and motivation through flexible leadership (Schein, 1985, 2004; Fairholm, 1994; Wills, 2001; Huţu, 2007). Conflicts will arise when managers do not even understand the tense situations because they do not have the appropriate cross-cultural leadership skills. Nevertheless understanding the cultural differences (Trompenaars and HampdenTurner, 1996) is key to build intercultural and cross-cultural competence (Hampden-Turner and Trompenaars, 2000). 


\section{Thomas-Kilmann Conflict Mode Instrument (TKI)}

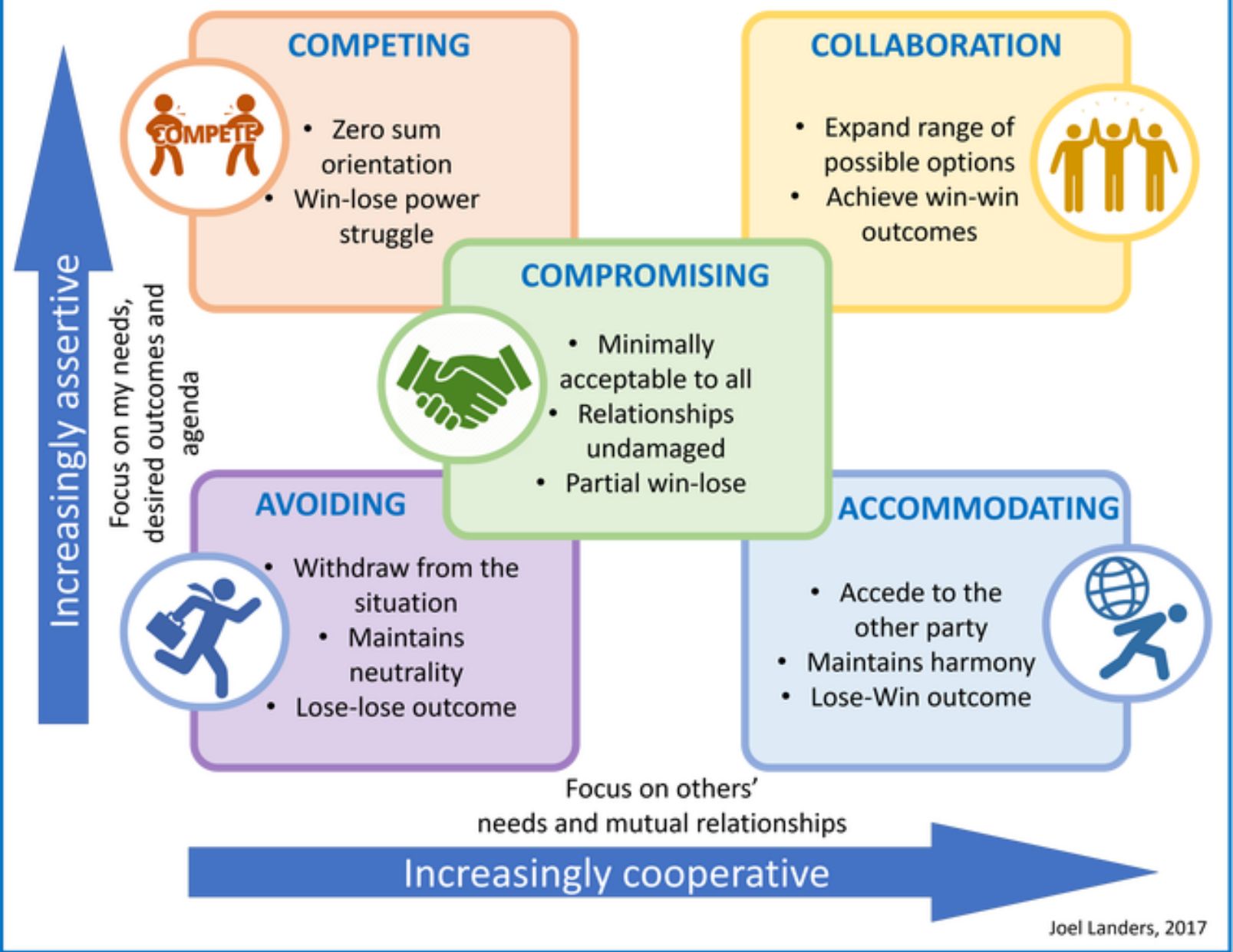

Figure 1. Conflict Model

Source: www.communicationinpublichealthweb.wordpress.com/mangement-styles-and-conflict

As the literature is rather scarce in analysing the specific cultural differences between Romanian and Indian actors - as well as their consequences - the focus of this paper is on this matter. The theoretical framework is the Hofstede model of national culture (Hofstede, 1991, 2003) - applied in case of Romania (Figure 2) and India (Figure 3). Comparing the two profiles, three differences are notable among the six dimensions: power distance, individualism, and uncertainty avoidance. This study is focused on the first two of them (the third might be the subject for future investigations). As regard to Romanian culture, a newer, more specific study on Romanian cultural profile was completed by Luca (2005), and significant elements were found by Draghicescu (2006).

This pilot study is part of a larger $\mathrm{PhD}$ research project; therefore, it is limited to projects and global project teams, mostly in financial services sector (qualitative research being conducted in a large international company providing financial services). 


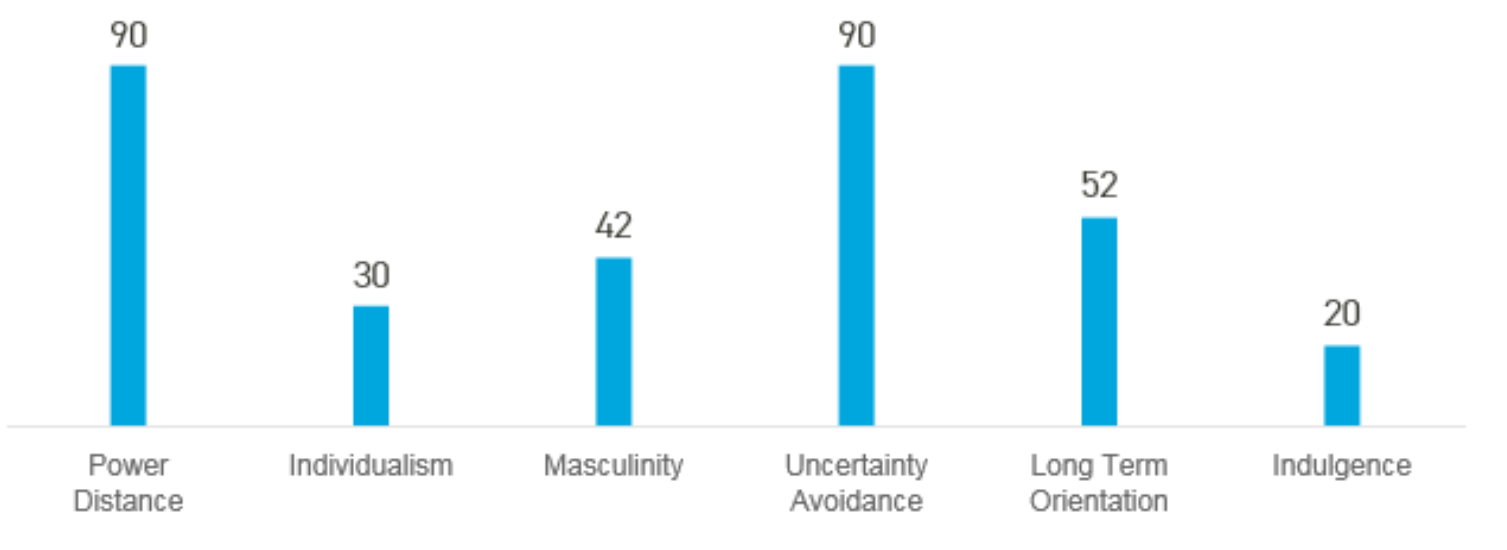

PICBE | 1027

Figure 2. Dimensions of national culture - Hofstede model - Romania

Source: https://www.hofstede-insights.com/models/national-culture

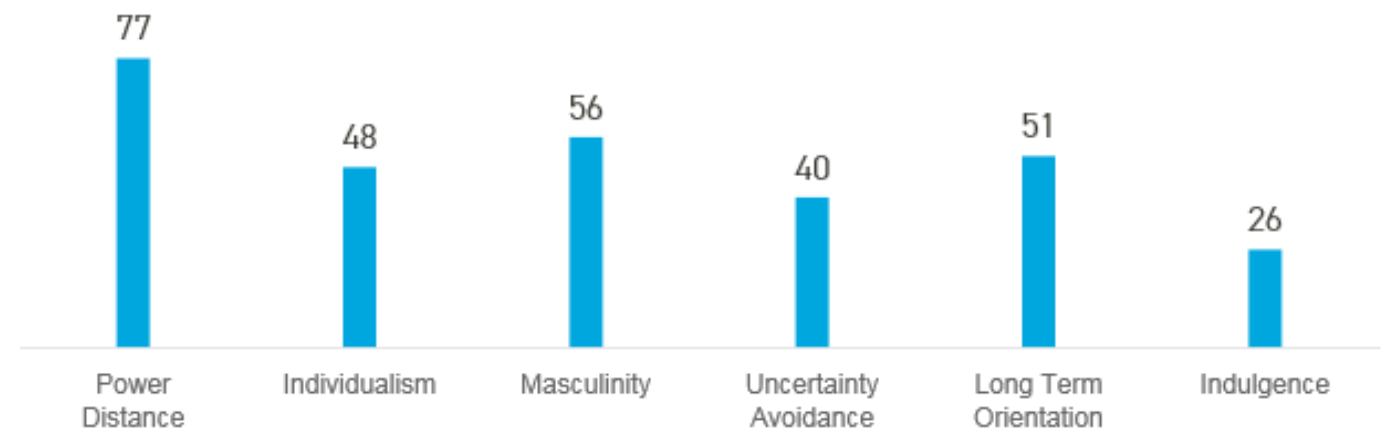

Figure 3. Dimensions of national culture - Hofstede model - India

Source: https://www.hofstede-insights.com/models/national-culture

\section{Methodological approach}

Methodological approach is to use both secondary literature survey and primary research methods as interviews and short case-examples from authors' direct consulting experience while working with global project teams. The research was essentially qualitative to collect information from experienced members of project teams on cross- cultural communication competence and multicultural team performance.

This study relates to three phases: (i) literature survey; (ii) focus-group and individual discussions analysing the Romanian versus Indian cultural dimensions - emphasizing power distance and individualism differences; (iii) interviews with managers with work experience in global project teams - aiming to identify causes of conflicts that occur while working in such teams. Using semi-structured, qualitative interviews, authors obtained in-depth information about the importance of conflict management into global project teams, the characteristics of cross-cultural conflict and collaboration, and common challenges of global project teams. 
The period of collecting data was winter 2019-2020 in a large international company active in financial services sector. Authors completed the in-house collected data with three short caseexamples from their own consulting experience (totalling more than five decades).

\section{Romanian vs. Indian cultural dimensions: power distance and individualism}

The Romanians versus Indian cultural dimensions of low/high power distance and collectivism/individualism are systematically presented, from the point of view of Romanian experts.

Organizational culture influence

As Triandis and Suh (2002) found, the culture influences the development of personalities and the way people resolve conflicts. A defining character of people in collectivist cultures is their notable concern with relationships. They showed that collectivists in conflict situations are primarily concerned with maintaining relationships with others, whereas individualists are primarily concerned with achieving justice. Collectivists prefer methods of conflict resolution that do not destroy relationships (e.g. mediation), whereas individualists are willing to go to court to settle disputes. Cultural and communication differences of team members influence team dynamics and an ability of a multicultural team achieve high levels of performance.

Romanian team members exhibit more emotional dependence on the team, are more conforming, orderly, traditional, particular, value interpersonal and interdependent relationships, ambitious to achieve harmony, and prefer autocratic or majority rule decision-making. Romanians use high-context and relationship-oriented communication and convey information deeply embedded in the context (Hall and Hall, 1990; Marquardt and Horvath, 2001). Therefore, the Romanian managers differ in their definitions and perceptions of appropriate and desirable communication behaviour when achieving high levels of team performance.

\section{Decision-Making}

On the contrary, in India, a group that often leads to indirect or procrastinated decision making always makes decisions. Decisions are always made only after consultation with higher officials and "Leadership" plays a significant role in the decision-making process. Work and family is the same for them; there is no separation between the private and professional person.

The fundamental issue addressed by this dimension is the degree of interdependence a society maintains among its members. It has to do with whether people's self-image is defined in terms of "I" or "We". In individualist societies people are supposed to look after themselves and their direct family only. In collectivist society's people belong to 'in groups' that take care of them in exchange for loyalty.

Romania, with a score of 30 , is considered a collectivistic society. In Romania, the society fosters strong relationships where everyone takes responsibility for fellow members of their group. In collectivist societies offence leads to shame and loss of face, employer/employee relationships are perceived in moral terms (like a family link), hiring and promotion decisions take account of the employee's in-group, management is the management of groups.

\section{Conflict management}

Indian people get emotional, at times physical, and raise their voices during a conflict. Soon they realize their behaviour and work at bringing in harmony.

In Romania, conflicts are resolved by compromise and negotiation. Incentives such as free time and flexibility are favoured. Focus is on well-being, status is not shown. 


\section{Indirect approach}

Indians work around the issue first and then move into it. India scores high on this dimension, 77, indicating an appreciation for hierarchy and a top-down structure in society and organizations.

Indians are dependent on the boss or the power holder for direction; accept of un-equal rights between the power-privileged and those who are lesser down in the pecking order; immediate superiors are accessible but one layer above less so. Leaders are paternalistic, management directs, gives reason / meaning to ones work life and rewards in exchange for loyalty from employees. Real power is centralized even though it may not appear to be and managers count on the obedience of their team members. Employees expect to be directed clearly as to their functions and what is expected of them. Control is familiar, even a psychological security, and attitude towards managers are formal even if one is on first name basis. Communication is top down and directive in its style and often feedback, which is negative, is never offered up the ladder. They try to resolve based on the knowledge that their inner circle has and do not communicate with the concerned person if they are out of the circle. They are reserved, but once you are in a circle, they open up very much.

Romania scores high on power distance dimension (score of 90), which means that people accept a hierarchical order in which everybody has a place and which needs no further justification. Hierarchy in an organization is seen as reflecting inherent inequalities, centralization is popular, subordinates expect to be told what to do and the ideal boss is a benevolent autocrat.

Granting respect

In India, superiors are role models and are always respected due to their titles. People never even think of contradicting their superiors. Their superiors have complete authority and are always right. Professional relationships are often converted into friendship or personal relationships, and therefore meetings can be held in cafes or hotels.

In Romania, there is an emotional need for rules (even if the rules never seem to work), time is money, people have an inner urge to be busy and work hard, precision and punctuality are the norm, innovation may be resisted, security is an important element in individual motivation.

\section{Causes of conflicts in project teams}

Authors' personal observations as well as semi-structured interviews with managers working in a large international financial services provider, with more than ten years of work experience in global project teams have identified most frequent causes of conflicts in project teams.

Conflicts can arise at any time during a project, leading to decreased productivity, loss of creativity and unwillingness to collaborate. Here are some common issues to watch out for.

1. Project team setup

Projects bring together individuals with various levels of experiences from different sectors. Team members will have their own approach to project setup, methodologies, documentation, reporting and so on. In addition, the team leader's management style can create frictions within the team.

\section{Communication}

Poor communication is at the root of many failed projects, so it is little surprise that communication leads to team conflict. Without a communication plan, team members quickly become confused about their work, priority tasks, and the overall purpose of the project.

Differences in individual communication style also cause tension; some team members may like to record every detail using e-mail whilst others may prefer a quick catch-up as needed.

3. Roles and responsibilities 
Problems quickly arise when team members do not know what they should be doing and how their work affects others. The blame-game often starts if a key task is overlooked or delayed because no one knew who owned the requirement.

\section{Stakeholder engagement}

With too much or too little engagement, frequent change requests, lack of internal buy-in stakeholders can support or disrupt the project progress in many ways!

PICBE $\mid 1030$

5. Scarce resources

Projects [i.e. project teams] are notoriously competing for resources, leading to rivalry within teams (in projects) and between departments (relative to organization). This problem is even more troublesome in organizations that plan projects by department or without a unique view of all projects across all teams.

6. Underperforming team members

Tensions will arise if some team members are not pulling their weight.

7. External vendors

Problems with communication, deadlines, contracts, and quality can lead to disagreements with external vendors. Unresolved, these issues can lead to missed deadlines and unhappy customers. Other sources of conflict can include team history, scope creep, schedule changes, declined change requests, or someone simply having a bad day.

\section{Inter-cultural case-examples in global project teams: Romanian versus Indian cultures}

This set of examples is meant to discuss not necessarily the Romanian versus Indian cultural differences but to illustrate that "national culture" label is risky to be applied in case of India. India is a huge country, actually a real sub-continent, not only the second most-populous country and the seventh largest one by area; it is also a secular federal parliamentary constitutional republic, made of 28 states and 8 union territories. Even though Hindi is the official language of the Indian Parliament and English is extensively used in administration and by business community, Republic of India has no national language - as it is home to two major language families (Indo-Aryan and Dravidian) as well as other two less spoken language families (Austroasiatic and Sino-Tibetan) so each state or union territory has one or more official languages! On top of this, amid dominance of Hinduism, there are other religions (Islamists, Christians, Sikhs, Buddhists, Jains, Zoroastrians, practicants of Bahá'i). Consequently, it is easy to understand why it is rather difficult and highly risky to start with a mindset of "Indian culture" while dealing with Indians - as the following examples demonstrate - all encountered during authors' international consulting practice.

Example 1.

In late 1990s, while working in an automotive plant in the UK, a young Romanian engineer had a Sikh Indian (from Indian state of Punjab) as direct manager - namely the leader of the project team in charge with launching in production of a new type of car engine - with the specific project objective of keeping the cost under a certain level. During half-year of direct interaction between the two actors in discussion, there was no conflict or cultural clash reported, in spite of the fact that the task has proved to be a tough, intensive, demanding, and also extremely stressful job. The Indian project manager proved to be a guide and mentor for the younger engineer. Conversely, the Romanian team member succeeded to change his boss's original mind-set that "Romanians are notso-hard-workers" (yet rather common among British population by that time). More than this, the two have extended the business relationship to friendship, exchanging not only family visits but cultural habits and language expressions as well.

Example 2. 
In mid 2000s, while working for a transnational consumer goods company at their London branch, a Romanian brand manager was leading a multi-national project team targeting the Indian market. In that capacity, she had to deal with Indian clients, specifically with an Indian project manager counterpart. The story of this project is almost a year-long, counting at least monthly trips from London to Chennai (Indian state of Tamil Nadu). Even so, what counts for our short case is not the number of trips and meetings between the two working teams but the fact that each meeting was punctuated by disagreements, conflicts and unpleasant situations - which originated in cultural differences, as explained by the people asked for feedback. The bottom-line is that, by the end of the project (although ended fairly successfully, with a deal closed), the Romanian brand manager decided "not to travel to India, anytime soon". Indian team's feedback was rather negative, too.

Each example bears its own conclusions and lessons learnt; lessons to be learnt by both sides, and for each team member belonging to certain national, organizational or family/individual culture. What authors intended to highlight by these two examples is twofold: (i) it is serious mistake to apply same label of cultural pattern to all parts of a country - mainly in case of multicultural conglomerates as India; (ii) yet within the same country, the cultural patterns - even when they are documented by large scale studies - apply statistically: even true, there are always exceptions.

Example 3.

During a turnaround project in Prague implemented by a Romanian consulting company in early 2010s, the Financial Services Lead was an Indian expert and the teams who worked to deliver services to client have included people of different European nationalities (Dutch, Czech, Slovak, Romanian, and German). The Romanian consultant was appointed to be part of the turnaround team and his main objective was to increase productivity and improve the quality of the service. After a few weeks of work, he discovered that - in spite of the fact that Indian was a very nice and polite person - the team members were really hating him for being pushy and staying literally "on their back" all the time. An explanatory discussion between the Romanian consultant and the Indian Lead (Why are you having this pushy and "at the people back" behaviour?) has revealed an unexpected cultural reason: in India, the Indian expert's experience was very positive and successful with that very common approach for his countrymen. The people from India (precisely Bangalore, state of Karnataka, former Mysore) were eager to stay after hours to finish their tasks when an upper level manager was giving constant attention to them.

... The Romanian consultant needed almost two months to convince the Indian expert that his approach was completely wrong as the Europeans hate this kind of behaviour.

This last example is probably the most convincing about the cultural differences between the Western "European culture" and the Oriental "Indian culture": how far is the paternalistic style of management from the individualistic nature of Westerners.

\section{Results, discussion and Lesson learnt:}

\section{To what extent can we talk about an Indian cultural archetype?}

The major lesson learnt following the examples above is that - beyond the fact that Oriental "Indian culture" is neatly more paternalistic than Western "European culture" - there is a large variety of national cultures within both of these: "Indian culture" is actually a mosaic of more than two dozens of national cultures, and same apply to European nationals (Romanian culture being just one of them). Yet, the concept of "national culture" - even in its second strict sense - is valid statistically; within same national population there are exceptions at all sides of the spectrum (e.g. there always are aggressive individuals in peaceful nations, and vice versa). 
It is not useless to mention that national culture is different than organizational culture (Drenan, 1992; Kummerow, Kirby and Xin, 2014). In this respect, it also is important to notice the difference between national culture at individual level (Early and Ang, 2003) - mostly as result of informal family education - and organizational business culture (assimilated as result of formal education mainly). Therefore, it is not baseless to launch a discussion about inter-cultural conflicts across hierarchies: it is expected that higher the hierarchical level, lower the number of PICBE | 1032 intercultural clashes (because in spite of [national] cultural differences, higher management level means higher quality business education - MBA-type education acquired, probably in the same prestigious business schools, possibly attending even the same MBA programme).

\section{Conclusions}

The authors use an integrative literature review to articulate the importance of intercultural dynamics, propose a discussion on this issue, introduce practical case-examples and identify new directions for future research. Understanding the intercultural dynamics has significant practical implications for both organizations and individuals, in particular for managers in multinationals while managing global project teams, in order to help organizations to navigate cultural complexity and foster cooperation among team members.

The results show how management can acquire useful information for the improvement of relationship between members of global project teams, especially regarding those aspects that seem to be more related to feedback, exchange of information, decision making, therefore, assumes a strategic importance and a systematic application of this analysis could be important in order to maintain or improve the collaboration and turning the cross cultural conflict into collaboration.

One of the key changes this study has triggered is the need to communicate effectively in different situations with people from different cultures and languages (Gardenswartz \& Rowe, 1998; 2003). The results obtained confirm the importance of communication and understanding of behaviour, attitudes, norms and values.

\section{Limitations and further research avenues}

As part of a larger $\mathrm{PhD}$ research project, this pilot study inherently has several limitations.

The main limit of this research is the reduced area of research - reduced to global project teams from just two cultures as well as industry (just one company active in the sector of financial services). However, the short case-examples (yet focused on the two cultures) come from a variety of other industries (automotive, production and distribution of consumer goods, business services). Further research aims at investigating other cultures than Indian interacting with Romanians as well as other companies (still within the financial services sector in the first phase, and then extended to other industries).

Comparing the two profiles, three differences are notable among the six dimensions: power distance, individualism, and uncertainty avoidance.

This study deals with two out of three major differences between the Romanian and Indian national profiles (power distance and individualism). The third (uncertainty avoidance) remains subject for future investigations.

Strictly from management perspective, it is challenging to explore the factors that might influence the cross-cultural management conflicts (e.g. intensity and level of conflicts by cultural and demographic characteristics - management experience and education in particular). 
Generally, the findings should be verified on a numerically higher sample that becomes representative (Weiss, 1994) for the universe of global projects teams. In addition, longitudinal studies are possible and will be practically useful - mostly in the current environment that undergoes rapid technological progress (West, 2002; Huţu, 2003). In this regard, it could be useful to consider more items or to refer to an analytical model of service quality that takes into greater consideration the perceived value by the people.

PICBE $\mid 1033$

\section{References}

Black, R.J. (2003) Organizational Culture: Creating the Influence Needed for Strategic Success. London, UK.

Bratianu, C. \& Bejinaru, R. (2019). The theory of knowledge fields: A thermodynamics approach. Systems, 7(2), 20, 1-12.

Bratianu, C., \& Bejinaru, R. (2020). Knowledge dynamics: A thermodynamics approach. Kybernetes, 49(1), 6-21.

Draghicescu, D. (2006) Din Psihologia Poporului Roman. Bucharest: Historia.

Drenan, D. (1992) Transforming Company Culture. London: McGraw-Hill Book Company.

Early, P.C. and Ang, S. (2003) Cultural Intelligence - Individual Interactions across Cultures. Stanford, California: Stanford University Press.

Eunson, B. (2009) Conflict Management. Retrieved from: https://ebookcentral.proquest.com/lib/uwsau/reader.action?ppg=22\&docID=903141\&tm= 1507701583586

Fairholm, G. (1994) Leadership and the Culture of Trust. Westport: Praeger Publishers.

Gallow, A. (2015) Podcast: ' 4 Types of Conflict and How to Manage Them'. Retrieved from: https://hbr.org/ideacast/2015/11/4-types-of-conflict-and-how-to-manage-them

Ganescu, C. (2011) Cultura organizațională şi competitivitatea. Editura Universitara.

Gardenswartz, L. \& Rowe, A. (1998) Managing Diversity: A Complete Desk Reference and Planning Guide. Revised Edition. McGraw-Hill.

Gardenswartz, L. \& Rowe, A. (2003) Diverse Teams at Work: Capitalizing on the Power of Diversity. Society for Human Resource Management.

Hall, E.I. and Hall, M.R. (1990) Understanding Cultural Differences. Garden City, New York: Intercultural Press.

Hampden-Turner, C. and Trompenaars, F. (2000) Building cross-cultural competence: how to create wealth from conflicting values. Yale University Press.

Hofstede, G. (1991) Cultures and Organizations. Software of the Mind. Intercultural Cooperation and its importance for survival. London: McGraw-Hill Book Comp.

Hofstede, G (2003) Culture and Organizations. International Cooperation and Its Importance for Survival. London, UK.

Huţu, C.A. (2003) Cultură, Schimbare, Competiţie. Cazul transferului de tehnologie in firme româneşti. Bucureşti: Editura Economica.

Huţu, C.A. (2007) Cultura organizațională şi leadership. Fundamentarea capacităţii competitive a firmei. București: Editura Economica.

Kotter, J.P., Heskett, J.L. (1992) Corporate Culture and Performance. New York: The Free Press. Kummerow, E., Kirby, N. and Xin, Y. (2014) Organisational culture: concept, context, and measurement. New Jersey: World Scientific. 
Landers, J. (2017) Communication in Public Health. ePortfolio. Retrieved from: https://communicationinpublichealthweb.wordpress.com/mangement-styles-and-conflict/

Luca, A. (2005) Employeescu. Bucureşti: Editura Pur şi Simplu.

Marquardt, M.J. and Horvath, L. (2001) Global Teams: How Top Multinationals Span Boundaries and Cultures with High-speed Teamwork. Davies-Black Pub.

Northouse, P.G. (2011) Introduction to Leadership: Concepts and Practice. Second Edition. SAGE PICBE | 1034 publications.

Proksch, S. (2016) Conflict Management. Springer.

Raymonde, C. (1998) Cultural Misunderstandings. Chicago: University of Chicago Press.

Schein, E.H. (1985) Organisational culture and leadership. New York: Jossey Bass

Schein, E.H. (2004) Organizational culture and leadership. Hoboken, New Jersey: John Wiley \& Sons.

Triandis, H.C. (1982) Review of culture's consequences: International differences in work-related values. Human Organizations, 41, 86-90.

Triandis, H.C. and Suh, E.M. (2002) Cultural Influences on Personality. Annual Review of Psychology, 53, 133-160.

Trompenaars, F. \& Hampden-Turner, C. (1996) Riding the waves of culture: Understanding cultural diversity. New York: McGraw Hill.

Weiss, R.S. (1994) Learning from strangers. The art and method of qualitative interview studies. New York: The Free Press.

West, M.A. (2002) Sparkling fountains or stagnant ponds: An integrative model of creativity and innovation implementation in work groups. Applied Psychology, An International Journal, $51,355-424$.

Wills, S. (2001) Developing global leaders. In P. Kirkbride \& K. Ward (Editors), Globalization: The internal dynamic, New York: John Wiley \& Sons, 259-284.

Zarzu, C.L., Scarlat, C. (2014, 2015) Knowledge management for knowledge development: lessons learnt while implementing international projects by multicultural teams. International Journal of Management Cases, Special Issue, 17(4), 2015, 221-231. 